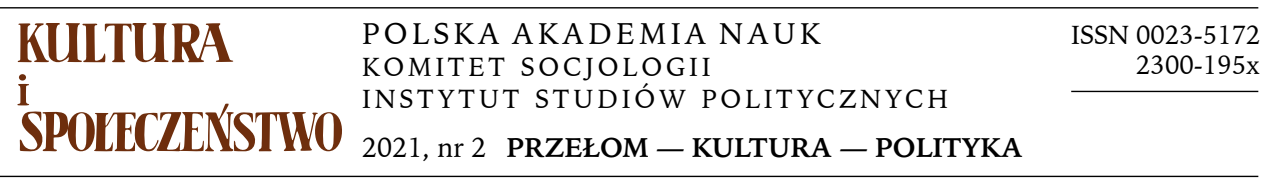
$\begin{array}{llllllll}A & R & T & Y & K & U & Ł & Y\end{array}$
I
$\begin{array}{llllllll}\mathrm{R} & \mathrm{O} & \mathrm{Z} & \mathrm{P} & \mathrm{R} & \mathrm{A} & \mathrm{W} & \mathrm{Y}\end{array}$

KRZYSZTOF OKOŃSKI

Uniwersytet Kazimierza Wielkiego w Bydgoszczy

\title{
WIZERUNEK NIEMCÓW W POLSKICH OBRAZACH FILMOWYCH OKRESU TRANSFORMACJI USTROJOWEJ
}

Upadek muru berlińskiego i rola Polski w procesie przemian demokratycznych w bloku wschodnim są przedmiotem wielu analiz w naukach humanistycznych i społecznych. Historyczny wymiar wydarzeń lat 1989-1990 znalazł odbicie między innymi w twórczości pisarzy niemieckich i jako „literatura przełomu” (Wendeliteratur) od ponad ćwierćwiecza odgrywa znaczącą rolę w kulturze pamięci RFN. Natomiat logotyp Solidarności i zdjęcia $z$ obrad Okrągłego Stołu, niegdyś obecne na pierwszych stronach gazet, straciły swój symboliczny wymiar w chwili upadku muru berlińskiego, który zaistniał w powszechnej świadomości jako znak końca zimnej wojny. Ikonograficzne ujęcie jego historii można podziwiać w zapisie koncertów rockowych (The Wall Rogera Watersa z 1990 roku), w filmach dokumentalnych (Królik po berlińsku), animacjach (Eingemauert/Zamurowani), grach komputerowych (Call of Duty: Black Ops - Berlin Wall) czy w spektakularnej oprawie rocznic wydarzeń 9 listopada 1989 r. (berlińskie domino, które w 2009 roku wprowadził w ruch Lech Wałęsa).

Uczestnicy tych wydarzeń zarówno w NRD, jak i w PRL reprezentowali szerokie spektrum postaw wobec systemu i jego upadku. W dorobku kinematografii polskiej i niemieckiej znajdują się filmy, które ilustrują tę różnorodność. Dzieli je nie tylko bariera językowa i tradycja filmowa, ale 
także poziom artystyczny, popularność oraz miejsce w kulturze pamięci — niezależnie od różnej wagi samego zagadnienia w kinematografii obu krajów.

Podejmuję tu analizę wizerunku Niemca w filmach, które powstały w czasie transformacji ustrojowej w Polsce lub dotyczą tego okresu. Sa to: Psy (reż. Władysław Pasikowski), Dwadzieścia lat później (reż. Michał Dudziewicz), Sauna (reż. Filip Bajon), Obcy musi fruwać (reż. Wiesław Saniewski), Yuma (reż. Piotr Mularuk) i Wróżby kumaka (reż. Robert Gliński). Dobór tych filmów i kolejność ich omówienia nie wynikają ani z chronologii, ani z kryteriów gatunkowych. Głównym powodem ich zestawienia jest fakt, że choć reprezentują raczej niewielką w polskiej kinematografii liczbę obrazów przełomu $z$ wątkiem niemieckim, to mogłyby stanowić (niezależnie od wartości poznawczej, jaką mają dla polskiego widza) pewnego rodzaju tematyczny suplement do obrazów transformacji autorstwa niemieckich reżyserów.

Jeżeli obraz Polski w kinematografii naszego sąsiada jest obarczony niekorzystnymi dla Polaków wyobrażeniami, to - przyjmując odwróconą optykę - spróbujmy zadać pytanie o obecność Niemca w polskich filmach. Eugeniusz Cezary Król nie pozostawia złudzeń:

„[...] wyraźna większość polskich filmów fabularnych z udziałem postaci Niemców traktuje tematykę niemiecką jako rekwizyt filmowy albo drugorzędne uzupełnienie akcji filmów. Tytuły, w których obraz Niemca wysuwa się na pierwszy plan, należą jednoznacznie — przynajmniej w sensie statystycznym - do mniejszości" (Król 2009, s. 133).

Mając na uwadze fakt, że zagadnienie stereotypów w kinie było (zwłaszcza w Polsce) przedmiotem wielu kompleksowych opracowań, w dalszych rozważaniach skupię się na koncepcji filmów jako intencjonalnych nośników pamięci historycznej (Marcin Kula), które stymulują polską pamięć o roku 1989 i latach późniejszych. Przy omawianiu tego zagadnienia warto wskazać na odmienność owej stymulacji w sferze publicznej w Polsce i w RFN:

„Porównując polskie i niemieckie dyskursy pamięci, łatwo dostrzec, że uczestniczą w nich odmienni aktorzy. W Polsce problemy związane ze stosunkiem do historii omawiane są przeważnie na arenie politycznej. Nawet jeśli u ich źródeł leżą prace naukowe czy publikacje literackie, to dyskutowane tematy zwykle dopiero wtedy wykraczają poza zacisza akademickich gabinetów i łamy fachowej prasy, gdy zainteresują się nimi politycy. [...] W Niemczech natomiast nieporównanie większą rolę $\mathrm{w}$ dialogu na temat pamięci zbiorowej odgrywają środowiska intelektualne: pisarze, publicyści, naukowcy" (Saryusz-Wolska 2009, s. 15-16). 
Oddajmy zatem głos filmowcom i kreowanym przez nich obrazom transformacji politycznej, społecznej i gospodarczej, w których pojawia się postać Niemca, pamiętając, że „[1]iteratura i film mają z natury rzeczy inaczej niż polityka, socjologia i nauki historyczne - prawo do swobodnego odbioru, traktowania i interpretacji tematów historycznych" (Braun 2013, s 9).

Celem zamieszczonego poniżej zarysu obrazu problematyki przełomu $\mathrm{w}$ kinie niemieckim jest wskazanie głównych wątków tematycznych w filmach naszego sąsiada oraz zasygnalizowanie $\mathrm{w}$ ten sposób zagadnień dotychczas w nich pomijanych. Pojawiają się one natomiat w wymienionych polskich filmach i dzięki nim mogłyby zaistnieć $\mathrm{w}$ dyskursie memorialnym w RFN - o ile widz niemiecki mógłby je obejrzeć.

Zarówno nurt rozliczeniowy, jak i „ostalgiczny” (od specyficznie wschodnioniemieckiego fenomenu Ostalgie: Ost=Wschód + nostalgia) w filmie zjednoczonych Niemiec był w Polsce przedmiotem analiz. W tym miejscu można wskazać na prace takich badaczy, jak Magdalena Saryusz-Wolska (2006), Ewa Fiuk (2012), Marta Brzezińska (2014), Andrzej Gwóźdź (2017), Andrzej Dębski (Leksykon...), Piotr Zwierzchowski (2013) czy Krzysztof Garczewski (Garczewski, Garczewska 2015). Przybliżono w nich polskiemu czytelnikowi nie tylko kanoniczne filmy, które trafiły do kin lub telewizji i mają ustaloną pozycję w historii kinematografii, lecz także tytuły znane odbiorcy w Polsce jedynie z niszowych pokazów lub nieobecne w krajowej dystrybucji.

Wątek związany z NRD nie zawsze gwarantował miejsce $\mathrm{w}$ pamięci niemieckich widzów - ilustrują to na przykład losy zapomnianego dzieła Franka Beyera Nikolaikirche/Kościót św. Mikołaja (1995) czy, przeciwnie, popularnego i wielokrotnie nagradzanego za granicą Goodbye, Lenin!. Diametralnie różną od znanej z tej drugiej produkcji wizję szoku kulturowego po upadku muru zawiera Berlin Is in Germany (reż. Hannes Stöhr, 2001), którego bohater patrzy na nowe Niemcy oczami byłego więźnia politycznego, uwolnionego dzięki pokojowej rewolucji w NRD. Do tytułów obecnych w pracach wspomnianych badaczy należałoby dodać najnowsze produkcje, między innymi Wir sind jung. Wir sind stark/Jesteśmy młodzi. Jesteśmy mocni (2014), Willkommen bei den Honeckers/Witamy u Honeckerów (2017) czy wreszcie rocznicowy (w 2019 roku minęło trzydzieści lat od upadku muru) i zapowiadany jako wydarzenie filmowe Wendezeit/Czas przełomu (2019). Ostatni tytuł mógłby idealnie pasować do tematyki tego artykułu, lecz lecz film zamiast refleksji nad transformacją społeczno-gospodarczą przedstawia fabułę typową dla thrillera politycznego (historia podwójnej agentki przed i po 1990 roku). Z kolei serial Weissensee, emitowany przez 
stację ARD i opowiadający o losach dwóch niemieckich rodzin w Berlinie Wschodnim od roku 1980 do okresu po zjednoczeniu Niemiec, to w niemieckiej produkcji filmowej jeden z niewielu wyjątków, traktuje bowiem także o okresie po 3 października 1990 r. Szczegółowo pisze o tym historyk i filmoznawca Andreas Kötzing:

„Historie kończą się nagle w okolicach upadku muru albo zjednoczenia. Żaden z filmów nie próbuje nawet wybiec poza cezurę lat 1989/1990. Trudno $z$ tego robić zarzut reżyserom. Fabuły filmów podążają za wewnętrzną logiką, według której zjednoczenie Niemiec jawi się obowiązkowo jako zakończenie opowieści" (Kötzing 2019).

Dalej Kötzing udowadnia, że tematy „transformacyjne” wręcz leżą na ulicy: zawodowe przeprofilowanie większości Niemców na Wschodzie, masowe bezrobocie, likwidacja i bankructwo państwowych przedsiębiorstw oraz społeczne skutki zmian (Kötzing 2019). Ten sam autor w wywiadzie dla gazety „Leipziger Volkszeitung” zwraca uwagę na pozornie oczywisty mankament produkcji filmowych o podziale Niemiec i o pokojowej rewolucji lat 1989/1990:

„W filmach fabularnych o NRD dominują poza tym tematy polityczne, jak historie ucieczek, a od czasów ogromnego sukcesu Życia na podstuchu przede wszystkim wszelkiego rodzaju opowieści o Stasi. To jest oczywiście uzasadnione, ale rozumiem też, że jest wielu ludzi z enerdowskimi życiorysami, którzy oglądają te filmy i zadają sobie potem pytanie: Ale co to ma właściwie wspólnego z moim życiem?" (Resch 2019).

Refleksja niemieckiego badacza przybliża nas do głównego tematu tych rozważań i pozwala zadać pytanie, czy polskie obrazy przełomu mogą uzupełnić niemiecką kulturę pamięci o dyskusję na temat zjawisk, które niegdyś były udziałem większości widzów pochodzących z dawnej NRD.

Analizując filmowe obrazy przełomu i wczesnego okresu transformacji oraz pojawiające się w nich postaci Niemców, trudno nie zestawiać ich z Psami. W opinii Ewy Mazierskiej obraz Władysława Pasikowskiego wyraża niezadowolenie i niepokoje odczuwane przez Polaków po przełomie 1989 roku: „teraźniejszość to [...] czas politycznego, społecznego i moralnego chaosu, w którym każdy musi odnaleźć dla siebie nowe miejsce i nowe wartości" (cyt. za: Copik 2019, s. 31).

Ogromny sukces komercyjno-frekwencyjny i kultowy status filmu nie wymagają przypomnienia lub szczegółowego omówienia. Pomijając fakt, że główny bohater nosi niemieckie nazwisko (podobnie Wolf i Gross) i znany jest jako Franz, trudno rozpatrywać ten film jako przejaw szczególnego zainteresowania reżysera historią i współczesnością kontaktów 
polsko-niemieckich. O grze brzmiącymi niemiecko nazwiskami Władysław Pasikowski powiedział w wywiadzie dla "Gazety Wyborczej”:

"-Bohaterowie «Psów» nazywają się tak z niemiecka: Maurer, Gross, Wolf...

— To taki mój żart, którego puenty nie zdradzam, ale częściowo odpowiem. Inspirowały mnie «Książki najgorsze» Stanisława Barańczaka. Stawia on tam prostą i prawdziwą tezę, że w milicyjnych powieściach milicjant musiał zawsze mieć polskie nazwisko, a zbrodniarz - niemieckie albo i żydowskie. A w naszym filmie wszystko miało być inne niż dotychczas" (Subbotko 2014).

Mimo często nieprzekładalnego, „soczystego” języka, który jest nieodłącznym elementem Psów, oraz nie zawsze zrozumiałych dla zagranicznego widza nawiązań do naszej rzeczywistości można ubolewać, że film Pasikowskiego poza emisją w telewizji MDR (23 czerwca 1995' ${ }^{1}$ ) i sporadycznymi pokazami na przeglądach filmów wschodnioeuropejskich ${ }^{2}$ nie spotkał się z zainteresowaniem publiczności i mediów w Republice Federalnej Niemiec — także jako polski wkład do niemieckich debat o dawnym aparacie bezpieczeństwa i jego funkcjonariuszach. Występowanie w fabule Psów wątku związanego z przestępczą działalnością w Polsce funkcjonariusza enerdowskiej Stasi mogłoby przecież stanowić pretekst do nawiązania dialogu $z$ odbiorca $w$ Niemczech i sprowokowania go, by zadał istotne pytania o zagraniczne uwikłania tamtejszych służb i adaptację byłych pracowników resortu Ericha Mielkego do zmieniających się warunków społeczno-ekonomicznych. Choć odpowiedź na takie pytania pozostaje wyłącznie w sferze przypuszczeń, to postać oficera Stasi, pojawiającego się $\mathrm{w}$ scenie śniadania $\mathrm{w}$ restauracji, odsłania przed polskim widzem (przynajmniej symbolicznie) deficyty niemieckich rozliczeń z komunizmem, nierzadko przecież w Polsce stawianych za wzór. Interlokutor b. majora SB Grossa (Janusz Gajos) pojawia się wprawdzie w krótkiej rozmowie na temat pośrednictwa $\mathrm{w}$ handlu amfetaminą, którą produkują bracia Słaby, lecz jego obecność skłania do refleksji nad patologiami występującymi także w niemieckiej transformacji ustrojowej. Zajmował się nimi między innymi Jürgen Roth, analizując na przykładach kilku krajów związkowych „symbiozę między politykami, przestępcami i przedsiębiorcami w niektórych regionach Niemiec" (zob. Friederichs 2009). Dziennikarz udowadnia, że hasło pokojowych demonstracji w NRD „Stasi na produkcję!” przez

${ }^{1}$ Por. https://www.filmdienst.de/film/details/65626/hunde [dostęp: 11.04.2021].

2 Np. Niemiecko-polsko-rosyjskie forum „Przemiana w pamięci”. Cottbus, Zielona Góra, Drezno 4-11 listopada 2015 lub goEast Symposium: Filmerbe der Umbruchszeit Mittel- und Osteuropa 1985-1999 . 
byłych funkcjonariuszy aparatu ucisku zostało potraktowane dosłownie i stali się oni „odnoszącymi sukcesy biznesmenami, o których względy się zabiega, chociaż w czasach przełomu zajmowali się oszustwami i defraudacją" (Friederichs 2009). Roth pisze ponadto o powiązaniach dawnych enerdowskich ubeków z rosyjską mafią. Obserwacje niemieckiego dziennikarza znajdują potwierdzenie w leksykonie Pełnomocnika Rządu RFN ds. Akt Służby Bezpieczeństwa b. NRD: „Dokonując podsumowania można stwierdzić, że penalne rozliczenie bezprawia, jakiego dopuszczało się Ministerstwo Bezpieczeństwa Państwowego, w znacznym stopniu się nie powiodło" (Herbstritt).

Premiery Psów (1992) i filmu Dwadzieścia lat później (1993) w reżyserii Michała Dudziewicza dzieli wprawdzie zaledwie rok, ale różnica w przedstawieniu policji politycznej jest ogromna — o recepcji obu dzieł nie wspominając. Chociaż tematyka lustracji i działalności aparatu bezpieczeństwa w PRL i NRD była wówczas stosunkowo aktualna i żywo komentowana, losy fikcyjnego Franza Maurera są lepiej znane polskiemu odbiorcy niż ekranizacja dramatycznej biografii Marii Hildebrandt - postaci, w gruncie rzeczy anonimowej, podobnie jak tysiące zwykłych obywateli NRD, którzy mają $\mathrm{w}$ swojej biografii podobne doświadczenia, i nie w Psach, a właśnie w filmie Dudziewicza mogłyby odnaleźć próbę filmowego przetworzenia wpływu aparatu represji na ich życie. Wspólne natomiast dla obu filmów jest powiązanie fabuły z historycznymi wydarzeniami, które rozgrywały się w okresie komunizmu i jego upadku. W przypadku Psów jest to między innymi palenie akt SB, weryfikacja funkcjonariuszy, rozwój zorganizowanej przestępczości i przenikanie byłych agentów do tego środowiska, a Dwadzieścia lat później (mimo wyraźnego polskiego wątku) opowiada o dramatycznych przeżyciach filmowej rodziny Hauserów, konfrontując widza $z$ wieloma aspektami życia w NRD. Przejawy małej stabilizacji i względnego dobrobytu w „oknie wystawowym RWPG” oraz poczucie rodzinnego szczęścia, wyraźne w początkowych sekwencjach filmu, zakłóca szantaż ze strony Stasi. Pojawia się propozycja nie do odrzucenia: rejestracja Stefana Hausera jako tajnego współpracownika lub pociągnięcie go do odpowiedzialności karnej za udział w wypadku i defraudację zakładowych funduszy. Sytuacja, w jakiej znalazł się bohater, nie różni się od metod zastraszania obywateli $\mathrm{w}$ innych krajach komunistycznych, jednak okoliczności tej historii oraz konsekwencje decyzji, podejmowanych zarówno przez rodzinę Hauserów, jak i przez wszechobecny aparat represji, pozwalają obnażyć enerdowski model represji. Tęsknota za innym światem, jaką za każdym razem odczuwa Stefan, spoglądając przez okno na świecący pełnym światłem neon Mercedesa po zachodniej stronie muru berlińskiego, 
donos sąsiadki, próba ucieczki balonem, sprawna akcja Ludowej Policji, która położyła kres marzeniom Hauserów, proces z udziałem uwikłanego w aparat represji adwokata, wieloletnie kary więzienia dla rodziców, skierowanie dwójki dzieci do sierocińca oraz zaaranżowana przez państwo adopcja (Wolfa przez niemiecką, a Monikę przez polską rodzinę) w filmowym skrócie pokazują obce polskim doświadczeniom (w każdym razie w podobnym natężeniu) metody represji w NRD.

Znamienne jest również odejście od klasycznego ukazania momentu upadku muru berlińskiego jako euforycznego przeżycia z udziałem tysięcy mieszkańców obu części podzielonego miasta. Kamera wychwytuje z wiwatującego tłumu Ewę i Stefana, którzy - inaczej niż większość berlińczyków - rezygnują z toastu szampanem i otwarcie granicy traktują jako możliwość odnalezienia swoich dzieci. Obraz agonii NRD obfituje również w wątki, które w najlepszym razie egzystują na marginesie polskich wspomnień o jesieni 1989: ucieczka wpław przez Odrę do Polski, organizacja na terenie ambasady RFN w Warszawie prowizorycznego obozu dla uciekinierów z NRD i okazana im pomoc ze strony mieszkańców Warszawy z jednej strony składają się na indywidualną pamięć bohaterki filmu, a $z$ drugiej przywołują zdarzenia mniej znane nie tylko młodszemu pokoleniu Polaków, ale nawet niemałej części Niemców, którzy masowe wyjazdy z NRD kojarzą głównie z historyczną sceną ogłoszenia przez Hansa-Dietricha Genschera na balkonie ambasady w Pradze możliwości wyjazdu na Zachód. Walor poznawczy filmu Dwadzieścia lat później odkrywamy głównie w związku z losami dwójki dzieci — oddzielonych przez enerdowski sąd od swoich rodziców, niegodnych miana obywateli socjalistycznego państwa i adoptowanych przez rodziny po obu stronach granicy. Proceder zwany Zwangsadoption (adopcja przymusowa) stanowi (obok sprzedaży za dewizy więźniów politycznych) jeden z najbardziej haniebnych aspektów historii NRD. Faktyczny zakres tego rodzaju praktyk w majestacie ówczesnego prawa jest nieznany, a w niemieckim internecie bez problemu można znaleźć adresy stron fundacji i instytucji zajmujących się poszukiwaniem i łączeniem rodzin rozdzielonych siłą przez komunistyczne państwo. Kara więzienia dla osób skazanych z „politycznych" paragrafów w rozumieniu enerdowskiego reżimu była wystarczającym powodem do rozbicia rodziny (Lindenberger 2018).

Mając na uwadze przytoczone wyżej konteksty historyczne obrazu w reżyserii Michała Dudziewicza można stwierdzić, że Dwadzieścia lat później jest przykładem filmu, który przybliżając polskiemu widzowi specyfikę wschodnioniemieckiego doświadczenia komunizmu i jego upadku, mógłby również zachęcić odbiorców w Niemczech do ożywienia pamięci 
o rzadziej pojawiających się w tamtejszej kinematografii i kulturze pamięci aspektach tamtejszej dyktatury ${ }^{3}$. Przeszkodą jest niestety brak tego filmu w dystrybucji w RFN (według filmdienst.de - największej niemieckojęzycznej filmowej bazy danych).

Sauna Filipa Bajona z 1992 roku jest filmem krańcowo odmiennym i jednocześnie stanowi rzadki w polskiej kinematografii przypadek spojrzenia na późną fazę komunizmu i jego upadek z dużą dozą humoru opartego na stereotypowych wyobrażeniach pozostałych „demoludów”. Oglądając film Bajona trudno powstrzymać się od zacytowania fragmentu eseju Richarda Wagnera, pochodzącego $z$ Rumunii niemieckiego publicysty i pisarza. Ukazał się on pierwotnie w berlińskim czasopiśmie „Kursbuch” (wydanie z września 1985), a w polskim przekładzie na łamach drugoobiegowego periodyku „Europa” (nr 2/1987):

„NRD jest kolonią. POLACY piją. CZESZKA jest blondynką. CZECH pije cały dzień piwo. WĘGIERKA jest napalona na WĘGRA. RUMUNI mają swojego Ceasescu. BUŁGARZY to MACEDOŃCZYCY. MACEDOŃCZYCY to właściwie BUŁGARZY. JUGOSŁOWIANIE oglądają JUGOSŁOWIAŃSKĄ telewizję. Stalinizmowi winni są ŻYDZI. ALBAŃCZYCY mogą się cieszyć: Enver Hodża nie żyje. Wkrótce CYGANIE będą stanowić większość. Ach, przyszliby wreszcie ROSJANIE" (Wagner 1987, s. 60).

Fabuła Sauny obejmuje okres 1980-1990, a bohaterami filmu są uczestnicy seminarium w Helsinkach, spotykający się regularnie w saunie tamtejszego Ministerstwa Edukacji. Pochodzą głównie z Europy Wschodniej, choć jest wśród nich też Amerykanin i Fin, obserwujący ze zdumieniem, jak wśród kolegów zza żelaznej kurtyny budzą się naznaczone politycznie antagonizmy. Temperatura $\mathrm{w}$ tym miejscu podnosi się o kilka dodatkowych stopni głównie za sprawą Polaka — Janka (w tej roli Bogusław Linda), dolewającego oliwy do ognia (a właściwie wódki do paleniska) przez wygłaszanie szyderczych uwag pod adresem pozostałych przedstawicieli krajów tzw. demokracji ludowej. Paradując w saunie $z$ ręcznikiem ozdobionym logo „Solidarności”, stara się sprowokować kolegów do komentarzy, po których w ich ojczystych krajach (zwłaszcza w ZSRR i w NRD) oblaliby się potem - zdecydowanie bardziej z powodu obawy o donos niż ze względu na stopień wilgotności powietrza w saunie. Ernst, stypendysta ze wschodnich Niemiec, próbuje zachować spokój w obliczu demonstracji „polskiego bakcyla wolności”, kwitując wystąpienie Janka słowami: „Siedzi Pan tyłkiem na «Solidarności»".

3 Por. film dokumentalny Żegnaj DDR! Przez Warszawę ku wolności (2009), reż. Krzysztof Czajka. 
Film Filipa Bajona pozornie epatuje stereotypami o „demoludach” i poprzez personifikację krajów komunistycznych w postaciach bohaterów pozwala przybliżyć widzowi czynniki historyczne i polityczne specyficzne dla danego państwa. Okazuje się, że nie tylko Polak jest przeciwnikiem ustroju — także Węgier Sabo ma w swoim życiorysie epizod oporu wobec komunizmu w 1956 roku. Trudno o równie jednoznaczne i konsekwentne deklaracje ideowe w przypadku Ernsta, który tłumaczy Jankowi: „Wiem, co Pan o mnie myśli - «posłuszny Niemiec». A ja nie myślę, tak jak mówię. Nie mogę Pana chwalić. [...] Wyznam szczerze, ja chciałem Panu zabrać ten ręcznik. Kiedy go zobaczyłem, to aż mi serce do gardła podskoczyło". Ten sam Ernst po wejściu do sauny Jurija natychmiast zmienia ton: „Strajki, strajki, a myśmy od ust sobie odejmowali i wam posyłali". Stypendysta ze wschodnich Niemiec uosabia w filmie Bajona statystycznego mieszkańca kraju Honeckera, o którym poeta, pieśniarz i pozbawiony obywatelstwa NRD dysydent Wolf Biermann powiedział dosadnie w wywiadzie dla podziemnej „Krytyki”: „Pamiętaj, że ponad 90\% obywateli NRD codziennie tkwi głową w zachodniej telewizji, a dupą w NRD. Niezbyt wygodna pozycja, ale interesująca" (Górka 1988, s. 73). Ernst zdaje jednak egzamin lojalności wobec polskiego „wichrzyciela” i to właśnie on w porozumieniu z Jankiem informuje wiernego radzieckiej ojczyźnie Jurija o wymyślonym przez Polaka przewrocie w Moskwie. Postać Ernsta (mimo drwin pod jego adresem) nie jest zatem zbudowana wyłącznie na podwójnym, nazistowsko-komunistycznym stereotypie obywatela NRD, który zgodnie $z$ antyfaszystowskim mitem założycielskim tego państwa skrzętnie skrywa ślady przeszłości sprzed 1945 roku, jednocześnie uczestnicząc w budowie socjalizmu pod radziecką kuratelą. Ironiczna uwaga o enerdowskim mariażu marksizmu z protestantyzmem, którą do Ernsta kieruje Janek, wydaje się przy tym nieuzasadniona, gdyż to między innymi Kościół ewangelicki stał się w NRD katalizatorem buntu obywateli podczas pokojowej rewolucji w 1989 roku, chociaż w nim także nie brakowało tajnych współpracowników Stasi i oportunistów. Trafniejsze byłoby nawiązanie w filmie do implementacji w warunkach dyktatury SED wybranych elementów pruskiej tradycji, o czym pisał brytyjski historyk Timothy Garton Ash w książce Niemieckość NRD. Ernst jako człowiek wykształcony i znawca niemieckiej kultury (kolejna „akademicka” rola Władysława Kowalskiego) pasuje ponadto do wizerunku wschodnioniemieckiego inteligenta, który mimo długiego stażu w służbie ludowemu państwu w przełomowej chwili staje po stronie demonstrantów (vide udział artystów w demonstracjach na berlińskim Alexanderplatz i innych akcjach jesienią 1989 roku). Dylematy ideowe wschodnioniemieckiego inteligenta ukazane z polskiej perspekty- 
wy nie mogły niestety zostać poddane osądowi widzów i krytyki w RFN, gdzie twórczość Filipa Bajona przybliżano na przykładzie innych dzieł tego reżysera, pomijając przy tym Saunę.

Zdecydowanie szerszą paletę postaw Niemców na Wschodzie - choć już po upadku muru berlińskiego i zjednoczeniu — prezentuje film w reżyserii Wiesława Saniewskiego, który Eugeniusz Cezary Król charakteryzuje następująco:

„Szczerze powiedziawszy, film zatytułowany Obcy musi fruwać (1993) należałoby zakwalifikować do gatunku absurdalnej groteski. Polski reżyser z Wrocławia (Breslau) wystawił sztukę teatralną w już zjednoczonym Berlinie. Po kompletnej klapie całego przedsięwzięcia wraca przygnębiony pociągiem do domu. W trakcie podróży polscy skinheadzi biorą go za Niemca i wyrzucają przez okno z pociągu. Pisarz zaczyna lewitować...” (Król 2009, s. 166).

Surrealistyczne zakończenie może istotnie budzić irytację widza, tym bardziej że wcześniejsze sekwencje filmu Saniewskiego zawierają wiele realistycznych odniesień do ówczesnej sytuacji w Niemczech i pozwalają poznać rozmaite zachowania Niemców między innymi wobec rodaków z b. NRD. Polscy artyści uzyskują wsparcie finansowe od znajomego niemieckiego małżeństwa, które zapewniając o swojej gotowości do niesienia im pomocy, sygnalizuje jednocześnie nowy konflikt w społeczeństwie niemieckim: „DeDeRonowi nie pożyczyłbym, ale Tobie zawsze”. Zacytowane zdanie ilustruje w skrótowy sposób zderzenie dwóch mentalności, które przed 1990 rokiem ukształtowały się po obu stronach wewnątrzniemieckiej granicy. Podział na Wessis i Ossis (pogardliwe określenia mieszkańców odpowiednio - zachodnich i wschodnich landów) jest jednym z najtrwalszych skutków podziału Niemiec i opisuje odmienność przyzwyczajeń, preferencji politycznych, postaw społecznych, stosunku do historii, religii, narodu, obcokrajowców i pracy. Różnice materialne między zachodnią i wschodnią częścią Niemiec od trzydziestu lat są wyrównywane, między innymi $z$ podatku solidarnościowego i innych środków federalnych, jednak niemal zawsze niemieckie dane statystyczne nawet dziś przywodzą skojarzenia $z$ rzucającymi się $w$ oko konturami zaborczych granic na współczesnej mapie Polski, na przykład przy próbie porównania infrastruktury i rozwoju społecznego regionów.

Kolejnym wątkiem filmu Obcy musi fruwać, mówiącym wiele o specyfice niemieckiego przełomu i jego skutkach dla tożsamości Niemców, jest niechęć wobec cudzoziemców, w tym Polaków. Wprawdzie niemiecka ksenofobia ma dziś inne niż dawniej oblicze i uwarunkowania (kryzys migracyjny, ogólnoeuropejskie tendencje narodowo-populistyczne, zama- 
chy terrorystyczne, problemy z integracją części muzułmańskich imigrantów itd.), jednak wschód Niemiec już we wczesnych latach dziewięćdziesiątych uchodził za „no-go-area” — głównie za sprawą agresji wobec obcokrajowców, podpaleń ośrodków dla azylantów i sympatii dla rozwijających się tam dynamicznie ruchów neonazistowskich. W jednej ze scen filmu polski bohater przygląda się kawalkadzie samochodów z kibicami, którzy świętują kolejny niemiecki cud w roku 1990 - mistrzostwo świata w piłce nożnej zdobyte przez reprezentację RFN. Morze niemieckich flag i demonstracja poczucia dumy narodowej szybko ustępują miejsca agresji ze strony neonazistów, którzy demolują polskiego fiata 126p i terroryzują jego pasażerów. Scenę napaści na Polaków wieńczy ujęcie berlińczyka, który z balkonu oklaskuje sprawców napadu. Trudno w tym momencie nie nawiązać do reakcji mieszkańców Rostocku, którzy dwa lata później podczas zamieszek na tle rasowym bili brawo bandom wyrostków podpalających wieżowiec dla azylantów. Przemoc wobec obcokrajowców była tematem nieistniejącym w oficjalnych mediach NRD - podobnie zresztą jak informacje o ich liczbie w kraju rządzonym przez Ericha Honeckera. W 1990 roku szacowano, że przebywa tam ok. 160000 osób, które przybyły z zagranicy, w tym 6500 z Polski, na podstawie umów bilateralnych o zatrudnieniu pracowników, co miało zaspokoić zapotrzebowanie na fachową siłę roboczą. W jednym z artykułów prasowych (Der Spiegel 1990, s. 98-106) znajduje się nawiązanie do tekstu z „Gazety Wyborczej”, który informuje o „psychozie wrogości wobec Polaków” i „brutalnym traktowaniu" polskich klientów w niemieckich sklepach. Okazało się, że ostentacyjna Freundschaft i internacjonalizm to jedynie propagandowe frazesy.

Fasadowość kontaktów między PRL i NRD oraz obywatelami obu państw omawiają szczegółowo autorzy wydanego w 2003 roku tomu pt. Zwangsverordnete Freundschaft? Die Beziehungen zwischen der DDR und Polen 1949-19904. Znany wschodnioniemiecki opozycjonista i podziemny wydawca Ludwig Mehlhorn we wstępie swojego tekstu o nakazanej przyjaźni między PRL i NRD zauważa, że po 1989 roku widoczny był brak komunikacji między Polakami i ich zachodnimi sąsiadami. Zastanawia się nad przyczynami tego stanu rzeczy i szybko dochodzi do wniosku, że określenie zawarte w tytule artykułu najlepiej wyjaśnia te wątpliwości - otóż nakaz i przyjaźń wzajemnie się wykluczają, przyjaźń może być pielęgnowana i rozwijana, ale w żadnym razie nie nakazana. Autor wspomina następnie,

4 Polskie wydanie ukazało się w 2009 nakładem wrocławskiej oficyny Atut pod tytułem: Przyjaźń nakazana? Stosunki między NRD i Polska w latach 1949-1990, Basil Kerski, Andrzej Kotula, Krzysztof Ruchniewicz, Kazimierz Wóycicki (red.). 
jak w czasach komunistycznych opozycjoniści i niezwiązani z partią intelektualiści używali terminu „przyjaźń nakazana”, chcąc opisać zakłamanie oficjalnej propagandy i kreowanego przez nią obrazu relacji między obydwoma państwami i społeczeństwami (por. Mehlhorn 2003, s. 35). Mimo groteskowego zakończenia film Obcy musi fruwać jest próbą wielowymiarowego spojrzenia na Niemcy (a częściowo także na Polskę) okresu przemian i w latach dziewięćdziesiątych mógłby doczekać się szerszej i wcześniejszej dystrybucji - jednak kinowa premiera miała miejsce dopiero w 2000 roku, a w 2004 film pokazano w prestiżowej berlińskiej Uranii ${ }^{5}$.

Film Yuma (2012) w reżyserii Piotra Mularuka przedstawia - inaczej niż Obcy musi fruwać - ignorancję, niechęć czy wręcz agresję wobec cudzoziemców, sąsiadów zza Odry, w jej polskim wymiarze. Obraz aktywności grupki młodocianych złodziei z Polski, działających na terenach przygranicznych, głównie we Frankfurcie nad Odrą, ożywia naszą pamięć o negatywnych skutkach przemian, takich jak właśnie rozwój przestępczości czy (nierzadko uzasadniana zaszłościami historycznymi) pogarda dla bogatszych Niemców. (Wschodnio)niemiecki widz natomiast, oglądając ten film, może zrelatywizować własne traumy, zestawiając je z wizją transformacji po drugiej stronie podzielonego Odrą (i granicą) miasta. Reżyser umieszcza fabułę w schyłkowej fazie komunizmu i wczesnych latach transformacji, widz może być zatem świadkiem nie tylko przemian rzeczywistości społeczno-gospodarczej okresu PRL i młodej III RP, lecz także ewolucji postaw bohaterów filmu. Kreśląc obraz życia w prowincjonalnym, trapionym biedą i beznadzieją przygranicznym miasteczku, Mularuk wykorzystuje dość nietypową dla filmów o tematyce polsko-niemieckiej ikonografię kina gangsterskiego i westernu (świadczy o tym zresztą nie tylko tytuł). Jednak z uwagi na problematykę tych rozważań należałoby raczej zaakcentować inny wątek, dający się opisać formułą „Za wolność naszą i waszą". Reżyser wprowadza go (chociaż oczywiście w przekorny sposób) w pierwszych scenach filmu, pokazując Ernsta, enerdowskiego uciekiniera, który na oczach Zygi - głównego bohatera - pokonuje wpław Odrę i ostatkiem sił wydostaje się na brzeg po polskiej stronie. Jest rok 1987 $\mathrm{i}$ jedyną szansą dla zbiega jest przetransportowanie go w tajemnicy do placówki dyplomatycznej RFN w Polsce, w czym paczka Zygi odgrywa kluczową rolę. Młody Polak nie wygłasza wzniosłych haseł o pomocy prześladowanym i początkowo odmawia przyjęcia zapłaty za transport. Polski widz śledzi tu pokazaną (podobnie jak w filmie Dwadzieścia lat później) udaną próbę ucieczki z NRD przez Odrę, chociaż należy zaznaczyć, że

${ }^{5}$ https://www.urania.de/stranger-must-fly-der-fremde-muss-fliegen [dostęp: 11.04.2021]. 
do czasów exodusu w 1989 nielegalne przekraczanie granicy planowano z uwzględnieniem innych kierunków i przeszkód - muru berlińskiego, przepływającej przez Berlin Sprewy, granicy wewnątrzniemieckiej czy Bałtyku. Postać uciekiniera z NRD i honorowe potraktowanie go przez Zygę to właśnie wspomniany powyżej epizod, luźno nawiązujący do słynnej polskiej formuły wolnościowej. Ernst jest jednak jedyną postacią zza zachodniej granicy, którą Zyga i przyjaciele (do pewnego momentu) traktują z sympatią. Wyłaniający się z filmu Mularuka obraz Niemca okresu przełomu politycznego w obu państwach daleki jest jednak od dziewiętnastowiecznego archetypu oczytanego i wrażliwego rewolucjonisty, dla którego dobro Niemiec jest najważniejszym imperatywem. Fakt, że mieszkańcy Frankfurtu zostają sportretowani jako anonimowi funkcjonariusze służb granicznych, policji i ochrony oraz właściciele sklepów, charakteryzujący się wyjątkową naiwnością i wiarą w uczciwość klientów, nie jest wynikiem uprzedzeń reżysera. Język niemiecki słychać w filmie bardzo rzadko, a jeśli się pojawia, to głównie po to, by bohaterowie filmowi mogli wyrazić pogardę dla Niemców, będących dla Zygi, jego kolegów, także dla polskiego burmistrza obywatelami wrogiego „Rajchu”, których należy łupić bez najmniejszych skrupułów, wręcz z poczuciem sprawiedliwości dziejowej: „Wiesz ile takich telewizorów musiałbyś przewieźć $\mathrm{w}$ ramach reparacji za zagrabione dobro?” - pyta Zygę burmistrz, rugając go jednocześnie za tolerowanie obecności Niemców i za narażanie jego uszu na dźwięk ich języka w polskim burdelu, który właśnie odwiedza.

Według badań przeprowadzonych w 1996 roku (zob. Oschlies 1996) Niemcy od 1975 roku ( $z$ tendencją spadkową w latach osiemdziesiątych) znajdowali się na czele listy narodów budzących niechęć Polaków, przy czym odnotowano wzrost negatywnych odczuć wobec Niemców z NRD. Niezależnie od późniejszego rozwoju Słubfurtu (transgranicznej aglomeracji, złożonej ze Słubic i Frankfurtu) oraz nasilenia kontaktów zawodowych, usługowych i handlowych po obu stronach granicy w 1990 roku wśród 64,4\% uczestniczących w badaniu Polaków odnotowano „najwyższy niepokój” w związku z perspektywą zjednoczenia Niemiec, a w czerwcu 1992 roku 50\% traktowało niemiecką jedność jako "zagrożenie dla polskich granic".

Wróćmy do wizerunku Niemca-uciekiniera z NRD: awansujący na przywódcę lokalnego półświatka Zyga stara się zaimponować dziewczynie ogromnym amerykańskim kabrioletem, jednak musi przyjąć do wiadomości, że jego rywalem jest Ernst, właściciel skromnego volkswagena "garbusa”. Dawny uciekinier z NRD wraca do Frankfurtu nad Odrą, aby pomóc rodzicom w prowadzeniu antykwariatu i oczywiście odwiedza polską 
dziewczynę, ryzykując zemstę ze strony swoich dawnych wybawców. Andrzej Kaluza w drugiej części swojej analizy pt. Alle reden Polnisch. Deutsch-polnische Geschichte im polnischen Film „Wszyscy mówia po polsku. Niemiecko-polska historia w polskim filmie" formułuje kilka krytycznych uwag dotyczących obsady Yumy. Pomijając wpływające na wiarygodność postaci paradoksy językowe w obsadzie ról (Ernsta, mówiącego łamanym polskim, gra Polak, natomiast jako Zyga występuje Jakub Gierszał, aktor który wychował się w Niemczech i świetnie mówi po niemiecku), Kaluza zgłasza swoje wątpliwości także w związku wyborami, jakich dokonują bohaterowie Yumy: „O ile sam film jest ogólnie rzecz biorąc wart obejrzenia, to widz nie wie, dlaczego piękna Polka Maja woli małomównego Niemca od miejscowego matadora Zygi” (Kaluza 2020). Można to wytłumaczyć stosunkowo licznymi (zwłaszcza w latach dziewięćdziesiątych) związkami Polek z Niemcami (przy nikłym zainteresowaniu Niemek małżeństwami z Polakami), ale problematyczna wydaje się (w kontekście sytuacji w Niemczech wschodnich po 1990 roku) konstrukcja biografii Ernsta. Obok mało prawdopodobnego faktu ucieczki przez Odrę w 1987 roku wiele pytań rodzi także los niemieckiego bohatera po zjednoczeniu. Czy powrót zdezelowanym garbusem z Hamburga do rodzinnego Frankfurtu nad Odrą i praca w rodzinnym antykwariacie mogą być ilustracją wschodnioniemieckich losów, w pierwszych latach po zjednoczeniu naznaczonych migracją (zwłaszcza młodych ludzi) do zachodnich landów, masowym bezrobociem, radykalizmem, poczuciem frustracji lub chęcią nadrobienia konsumpcyjnych zaległości na wymarzonym Zachodzie? Polsko-czeska koprodukcja, opowiadająca o transformacji językiem westernu, w Niemczech trafiła niestety jedynie do projekcji w ramach lokalnych przeglądów filmowych (np. 22. Festiwal w Cottbus).

Z kolei wyreżyserowana przez Roberta Glińskiego ekranizacja opowiadania Unkenrufe Güntera Grassa (1992) w Polsce ukazała się pod tytułem Wróżby kumaka w 2005 roku. Pierwowzór literacki był kolejnym powrotem niemieckiego pisarza do jego rodzimego Gdańska lub - jak zauważył sarkastycznie Marcel Reich-Ranicki (1992, s. 254-263) w recenzji dla „Der Spiegel” - przejawem ogólnie znanej tęsknoty Grassa za latami szkolnymi. Pomijając wymianę uszczypliwości między zwanym papieżem literatury niemieckiej Reich-Ranickim a urodzonym w Wolnym Mieście Gdańsku noblistą, należy obiektywnie stwierdzić, że Unkenrufe, mimo entuzjastycznej recenzji chętnie czytanego wówczas w Niemczech Andrzeja Szczypiorskiego (1992, s. 263-265), miała zdecydowanie słabszy (i raczej negatywny) odbiór niż większość powieści Grassa. Powieść zawiera wprawdzie pewne odniesienia do postaci i wydarzeń w Niemczech, jednak jej fabuła osadzona jest w Gdańsku i rozpoczyna się jesienią 1989 ro- 
ku. Filmowy wizerunek Niemca jest w tym wypadku odzwierciedleniem nakreślonych na kartach książki postaci, o których Frank Schirrmacher, znany niemiecki dziennikarz i redaktor naczelny „Frankfurter Allgemeine Zeitung”, napisał, że Grass zdegradował ich do rangi mówiących automatów, wypowiadających poglądy polityczne i opinie pisarza (zob. Hägele 2007, s. 603). Widz poznający fabułę Wróżb kumaka na podstawie polsko-niemieckiej koprodukcji filmowej jest konfrontowany głównie z postacią Alexandra Reschke, historyka sztuki, który w celach naukowych przyjeżdża do Gdańska i przez przypadek poznaje Aleksandrę Piątkowską, polską konserwatorkę zabytków, z którą po pewnym czasie nawiązuje romans. Miłość Niemca i Polki jest jednak pretekstem do przedstawienia historii fikcyjnego polsko-niemiecko-litewskiego towarzystwa cmentarnego, którego idea powstaje podczas jednej z rozmów obojga bardzo już dojrzałych kochanków, niegdyś wypędzonych z dawnej - gdańskiej i wileńskiej ojczyzny. Reschke faktycznie do pewnego stopnia jest alter ego Grassa interesuje się sztuką, ma w swojej biografii dziecięcy epizod członkowstwa w Hitlerjugend, jest zainteresowany ideą pojednania i reprezentuje typ niemieckich intelektualistów, o których mieszkający w Monachium Tadeusz Nowakowski (1961, s. 92) pisał, że sprawiają wrażenie ,jakby z lekka Polską zamroczonych, duchowo zataczających się na nogach”. Mając na uwadze polskie lęki przed Niemcami z wczesnego okresu transformacji, warto jednak skupić się na drugoplanowych bohaterach filmowej adaptacji książki Grassa. Okazuje się, że niemieccy emeryci, których widok w polskich kurortach nikogo dziś nie dziwi, po upadku komunizmu wykorzystują szansę, by przynajmniej jesień życia spędzić w dawnych rodzimych stronach. Stają się tym samym — mówiąc korporacyjnym językiem — idealnym targetem dla ludzi powiązanych z towarzystwem cmentarnym. O ile dla Reschkego nieuchronność śmierci byłych mieszkańców Wolnego Miasta nie wyklucza możliwości dania im szansy pochówku w ojczystej ziemi, o tyle dla pokolenia rzutkich biznesmenów i działaczy politycznych z RFN sentymenty są jedynie warunkiem sukcesu ich - zdecydowanie doczesnych - projektów. Jednym z takich ludzi jest przedsiębiorca budowlany Vielbrand, posiadający sporą gotówkę i chęć jej zainwestowania w na przykład w pola golfowe i inną infrastrukturę, która miałaby umilić jesień życia przybywającym do Gdańska starym Danzigerom. Towarzystwo cmentarne, którego nazwa $z$ czasem traci swój litewski człon, staje się łakomym kąskiem także dla zasiadającej w jego radzie Johanny Detlaff ze Związku Wypędzonych, która ma na uwadze własne cele polityczne, związane z symbolicznym powrotem na dawny niemiecki Wschód. Analizując z perspektywy czasu „sumę wszystkich strachów” Grassa pokazanych w filmie 
Glińskiego, można zauważyć, że przestrogi pisarza, socjaldemokraty z długim stażem, formułowane we wczesnym stadium transformacji, pasują idealnie (co za paradoks!) do obecnej prawicowej narracji o niemieckim zagrożeniu kulturowym, politycznym i ekonomicznym. Mimo stosunkowo słabej recepcji w Niemczech filmu i jego literackiego pierwowzoru dzieło Glińskiego (z pewnością także ze względu na nazwisko Grassa) nie podzieliło losu omówionych wcześniej filmów i mogło liczyć, oprócz odzewu w czołowych dziennikach (zob. np. Klabuhn 2004, s. 45), także na niemieckojęzyczną edycję DVD, dystrybucję kinową i emisję w telewizji ARD.

Upadek muru berlińskiego, czerwcowe wybory w Polsce, a jednoczesnie szok wczesnej fazy transformacji ustrojowej to doświadczenia, które ukształtowały generację dzisiejszych pięćdziesięciolatków wchodzących w dorosłość w 1989 roku. Omówione tutaj filmy z perspektywy trzydziestu lat mogą wydawać się archaiczne oraz dalekie od kwestii, którymi obecnie żyją Polacy i Niemcy, zwłaszcza młodsze pokolenia. Jeśli założymy, że jedną z przyczyn polaryzacji społecznej w Polsce (a także w Niemczech) jest stosunek do przeszłości, to nawiązując do wspomnianej na początku koncepcji Marcina Kuli, warto przyjrzeć się wspomnianym w artykule filmom jako intencjonalnym nośnikom pamięci historycznej, które nie tylko funkcjonują w pewnej rzeczywistości, ale też mogą ją zmieniać. Rozwój mediów znacznie ułatwia ten proces - dowodem jest ponad 150000 wyświetleń w serwisie YouTube dość niszowego filmu Dwadzieścia lat później (stan na wrzesień 2020). Wobec nikłej obecności tych filmów w niemieckiej dystrybucji warto nawiązać na przykład do funkcjonującego już projektu Studia Filmowego TOR, który polega na popularyzacji klasycznych polskich filmów z angielskimi napisami, i uzupełnić tę inicjatywę o możliwość wyboru niemieckiej wersji językowej. Zaprezentowany w tych filmach obraz polskiej transformacji ustrojowej przechowuje pamięć o naszych ówczesnych wyobrażeniach związanych z Niemcami, o polskich oczekiwaniach i lękach $z$ wczesnych lat dziewięćdziesiątych. Wydaje się, że to wystarczające powody do ich upowszechnienia za zachodnią granicą, zwłaszcza $z$ myślą o odbiorcach we wschodnich landach RFN. Wprowadzenie niemieckich bohaterów - uciekinierów z NRD, oportunistów i przeciwników reżimu, ofiar przymusowej adopcji, ale także funkcjonariuszy Stasi czy neonazistów - pozwala na podstawie obcych nam (w tej skali) doświadczeń zrelatywizować nasze subiektywne wspomnienia z poprzedniego ustroju i okresu przemian oraz przyczynić się do bardziej zróżnicowanej 
oceny ostatnich trzydziestu lat. Z kolei polska perspektywa (podobnie jak obecna w kinie niemieckim optyka migracyjna) może wzbogacić niemieckie spojrzenie na upadek muru berlińskiego i proces zjednoczenia o wiedzę na temat polskiego echa zmian w Niemczech, udziału Niemców w transformacji systemowej w Polsce oraz o doświadczenia Polaków związane z NRD i jej upadkiem.

\section{BIBLIOGRAFIA}

Braun Michael, 2013, Einführung: Erinnerungskultur 2012, w: Wem gehört die Geschichte? Erinnerungskultur in Literatur und Film, Aschendorff Verlag, Münster.

Brzezińska Marta, 2014, Spektakl - granica - ekran. Mur berliński w filmie niemieckim, Atut, Wrocław.

Copik Ilona, 2019, Na zakręcie. Krajobraz polskiej transformacji w filmach przełomu lat 80. i 90., „Kwartalnik Filmowy”, nr 105-106, s. 23-38.

Der Spiegel, 1990, „Schon nahe am Pogrom“, „Der Spiegel”, nr 14, 2 kwietnia, s. 98-106.

Dębski Andrzej, Obraz Polski i Polaków w filmie niemieckim oraz Niemiec i Niemców w filmie polskim po 1945 r., Interakcje, w: Leksykon komunikowania polsko-niemieckiego (http://www.polskaniemcy-interakcje.pl/articles/show/36, [dostęp: 29.08.2020]).

Filmdienst, https://www.filmdienst.de/film/details/65626/hunde [dostęp: 11.04.2021].

Fiuk Ewa, 2012, Inicjacje — tożsamość - pamięć. Kino niemieckie na przetomie wieków, Atut, Wrocław.

Friederichs Hauke, 2009, Mafïses Deutschland, Zeit Online, 13 marca (https://www.zeit.de/online/2009/10/mafia-roth/komplettansicht [dostęp: 29.08.2020]).

Garczewski Krzysztof, Garczewska Anna, 2015, Polskie i niemieckie narracje historyczne w filmach na tle prawa i polityki, Akademia Humanistyczna im. Aleksandra Gieysztora, Pułtusk.

Górka Małgorzata, 1988, Człowiek ze Wschodu. Rozmowa z Wolfem Biermannem, „Krytyka”, nr 30, s. $69-80$.

Gwóźdź Andrzej, 2017, Krajobrazy z murem berlińskim w filmach fabularnych podzielonego kina do roku 1989, w: Barbara Kita, Magdalena Kempna-Pieniążek (red.), Filmowe pejzaże Europy, Wydawnictwo Uniwersytetu Śląskiego, Katowice.

Hägele Christoph, 2007, Skandal oder Inszenierung?, w: Stefan Neuhaus, Johann Holzner (red.), Literatur als Skandal. Fälle - Funktionen - Folgen, Vandenhoeck \& Ruprecht, Göttingen, s. 598-612.

Herbstritt Georg, MfS-Lexikon. Strafverfolgung wegen MfS-Unrechts (https://www.bstu.de/mfslexikon/detail/strafverfolgung-wegen-mfs-unrechts [dostęp: 28.02.2020]).

Kaluza Andrzej, 2020, Alle reden Polnisch. Deutsch-polnische Geschichte im polnischen Film (2), DPI-Blog, 28 maja (https://www.deutsches-polen-institut.de/blog/alle-reden-polnischdeutsch-polnische-geschichte-im-polnischen-film-2/ [dostęp: 28.05.2020]).

Klabuhn Julia, 2004, „Unkenrufe“ als Film. Bei jedem Schritt muß er sich vergewissern, „Frankfurter Allgemeine Zeitung", 26 listopada, nr 277, s. 45.

Kötzing Andreas, 2019, Neue Bilder braucht das Land. DDR-Geschichte und Nachwendezeit in aktuellen Filmen, zeitgeschichte | online, 8 pażdziernika (https://zeitgeschichte-online.de/film /neue-bilder-braucht-das-land, [dostęp: 13.01.2020]). 
Król Eugeniusz Cezary, 2009, Obraz Niemców w polskim filmie fabularnym w latach 1946-1995. Przyczynek do studiów nad mitami i stereotypami narodowymi, „Biuletyn Polskiej Misji Historycznej", nr 5, s. 129-170.

Lindenberger Thomas, 2018, Dimension und wissenschaftliche Nachprüfbarkeit politischer Motivation in DDR - Adoptionsverfahren 1966-1990. Vorstudie im Auftrag des Bundesministeriums für Wirtschaft und Energie, Potsdam, den 20.Januar 2018 (Überarbeitung der Fassung vom 15. September 2017), Zentrum für Zeithistorische Forschung, Potsdam.

Mehlhorn Ludwig, 2003, Zwangsverordnete Freundschaft? Zur Entwicklung der Beziehungen zwischen der DDR und Polen, w: „Zwangsverordnete Freundschaft?“ Die Beziehungen zwischen der DDR und Polen 1949-1990, Osnabrück, s. 35-40.

Nowakowski Tadeusz, 1961, Bezdomna lewica, „Kultura” [Paryż], nr 10, s. 87-97.

Oschlies Wolf, 1996, Tschechen, Polen, Deutsche 1990-1996, t. 2: Stereotype und Realitäten, w: Berichte / BIOst, Bundesinstitut für ostwissenschaftliche und internationale Studien (https://nbn-resolving.org/ urn:nbn:de:0168-ssoar-42453 [dostęp: 07.02.2020]).

Reich-Ranicki Marcel, 1992, Wie konnte das passieren? Marcel Reich-Ranicki über das neue Buch von Günter Graß: „Unkenrufe“, „Der Spiegel”, nr 19, s. 254-263.

Resch Christopher, 2019, Friedliche Revolution: Es fehlt ein Film über die Nach-Wendezeit, Leipziger Volkszeitung, 22 października (https://www.lvz.de/Leipzig/Lokales/FriedlicheRevolution-Es-fehlt-ein-...1 [dostęp: 01.03.2020]).

Saryusz-Wolska Magdalena, 2006, Obraz NRD we wspótczesnym kinie niemieckim, w: Barbara Kita (red.), Przestrzenie tożsamości we wspótczesnym kinie europejskim, Rabid, Kraków.

Saryusz-Wolska Magdalena, 2009, Wprowadzenie, w: Magdalena Saryusz-Wolska, Pamięć zbiorowa i kulturowa. Wspótczesna perspektywa niemiecka, Universitas, Kraków, s. 15-16.

Subbotko Donata, 2014, Najpierw napisatem scenariusz pod tytułem „Policjanci z Warszawy”, „Gazeta Wyborcza", 29 maja (https://wyborcza.pl/piatekekstra/1,129155,16059659,Najpierw_napisalem_scenariusz_pod_tytulem__Policjanci.html [dostęp: 11.04.2021]).

Szczypiorski, Andrzej, 1992, Fröschegequak und Krähengekrächz. Adrzej Szczypiorski über „Unkenrufe“ von Günter Grass, „Der Spiegel”, nr 19, s. 263-265.

Wagner Richard, 1987, Między braćmi. Rejestr wschodnioeuropejskich nienawiści, „Europa”, nr 2, s. 60-65.

Zwierzchowski Piotr, 2013, Recepcja kinematografii NRD w polskim piśmiennictwie filmowym 1949-1990, w: Andrzej Dębski, Andrzej Gwóźdź (red.), W drodze do sasiada. Polsko-niemieckie spotkania filmowe, Atut, Wrocław.

\title{
THE PORTRAYAL OF GERMANS IN POLISH FILMS DURING THE TRANSFORMATION PERIOD
}

\author{
Krzysztof Okoński \\ (Kazimierz Wielki University)
}

\section{Abstract}

In Poland, the changes started with the Round Table talks and June elections, and in the GDR with the fall of the Berlin Wall. They gained momentum with the transformation of the Polish People's Republic into the Republic of Poland and the 
accession of the German Democratic Republic to the Federal Republic of Germany. These processes were reflected in literature, film, music, and even computer games. Artistic attempts to face the new reality acquired a special dimension in Germany, where the term "breakthrough literature" appeared. The international success of such productions as The Lives of Others or Goodbye, Lenin! indicates the great interest of German film directors in the subject as well. Similar attempts were made in Poland. Films appeared in which German characters-refugees from the GDR, businessmen, tourists, regime officials, or criminals-were presented in connection with the native heroes (usually in the background). An analysis of these characters allows us to look at the Polish experience of the last thirty years from a different perspective and to make a certain relativization of the changes that have occurred in Poland. In accord with Marcin Kula's concept, the author treats selected films as "historical memory carriers" and analyzes the image of Germans in films created during the political transformation in Poland or in films that concern this period: Psy (Dogs, directed by Władysław Pasikowski), Dwadzieścia lat później (Twenty Years Later, directed by Michał Dudziewicz), Sauna (directed by Filip Bajon), Obcy musi fruwać (The Foreigner Must Go, dir. Wiesław Saniewski), Yuma (dir. Piotr Mularuk) and Wróżby kumaka (Call of the Toad, dir. Robert Gliński).

key words: PPR, GDR, Polish-German relations, 1989, the breakthrough period in film

stowa kluczowe: PRL, NRD, stosunki polsko-niemieckie, rok 1989, czas przełomu w filmie 